\title{
Threatened fishes of the world: lotichthys phlegethontis Cope, 1874 (Cyprinidae)
}

Joseph H. Hanks

Brigham Young University - Provo

Mark C. Belk

Brigham Young University - Provo, mark_belk@byu.edu

Follow this and additional works at: https://scholarsarchive.byu.edu/facpub

Part of the Biology Commons

\section{Original Publication Citation}

Hanks, J.H., and M.C. Belk. 2004. Threatened fishes of the world: lotichthys phlegethontis Cope, 1874 (Cyprinidae). Environmental Biology of Fishes 71:378.

\section{BYU ScholarsArchive Citation}

Hanks, Joseph H. and Belk, Mark C., "Threatened fishes of the world: lotichthys phlegethontis Cope, 1874 (Cyprinidae)" (2004). Faculty Publications. 5451.

https://scholarsarchive.byu.edu/facpub/5451

This Peer-Reviewed Article is brought to you for free and open access by BYU ScholarsArchive. It has been accepted for inclusion in Faculty Publications by an authorized administrator of BYU ScholarsArchive. For more information, please contact ellen_amatangelo@byu.edu. 
See discussions, stats, and author profiles for this publication at: https://www.researchgate.net/publication/225846948

\section{Threatened fishes of the world: Iotichthys phlegethontis Cope, 1874} (Cyprinidae)

Article in Environmental Biology of Fishes · December 2004

Dol: 10.1007/s10641-004-1030-x

\section{CITATIONS}

2 authors:

Joseph H. Hanks

Brigham Young University - Provo Main Campus

8 PUBLICATIONS 73 CITATIONS

SEE PROFILE
READS

44

Mark C. Belk

Brigham Young University - Provo Main Campus

143 PUBLICATIONS 2,774 CITATIONS

SEE PROFILE

Some of the authors of this publication are also working on these related projects:

Project Phylogeography and landscape genetics of aquatic fauna in Patagonia View project

Project Least Chub Demography View project 


\title{
Threatened fishes of the world: Iotichthys phlegethontis Cope, 1874 (Cyprinidae)
}

\author{
Joseph H. Hanks \& Mark C. Belk \\ Department of Integrative Biology, Brigham Young University, Provo, UT 84602, USA \\ (e-mail:jhh49@email.byu.edu)
}

Common name: least chub. Conservation Status: Iotichthys phlegethontis is currently listed as a candidate species under the federal Endangered Species Act. Identification: Iotichthys phlegethontis is a small cyprinid, maximum length of $64 \mathrm{~mm}$ with relatively large scales, between 34 and 38 lateral scales, but with no lateral line (Sigler \& Sigler 1996). The mouth is oblique and the lips are even (Sigler \& Sigler 1987, 1996; Page \& Burr 1991). Iotichthys phlegethontis is sexually dimorphic, males tend to be smaller and more colorful than females

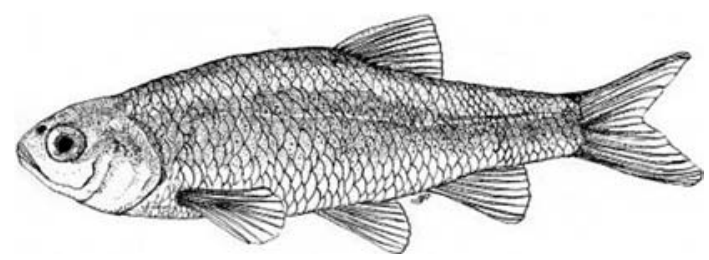
(Crawford 1979). Illustration by DawnRay Ammon. Distribution: Iotichthys phlegethontis is endemic to the Bonneville Basin, western USA. Its original range included the Sevier Lake drainage, Utah Lake drainage, portions of the Great Salt Lake drainage, and several isolated springs in the west desert area of Utah. Its current native distribution is reduced to five spring populations: Bishop Springs, Leland Harris Springs, and Gandy Salt Marsh Springs in Snake Valley (Millard County), Mills Valley Springs (Juab County), and Mona Springs (Juab County). Iotichthys phlegethontis has been introduced to Lucin Pond (Box Elder County), Antelope Springs on Antelope Island in the Great Salt Lake (Davis County), and Walter Springs at Fish Springs National Wildlife Refuge (Tooele County). Captive populations of I. phlegethontis are currently maintained at Fisheries Experimental Station in Logan, Utah and Wahweap Fish Hatchery in Page, Arizona (K.W. Wilson, Utah Division of Wildlife Resources, personal communication, Sigler \& Sigler 1987, 1996). Abundance: Historical abundance of I. phlegethontis is poorly documented. In currently inhabited locations (isolated spring heads) populations of several thousand individuals are typical (M.C. Belk personal observation). Habitat and ecology: Iotichthys phlegethontis feeds on algae, diatoms and midges (larvae and adults) in heavily vegetated, slow-moving, often alkaline waters (Sigler \& Sigler 1987). It attains a maximum age of 7 years (M.C. Belk unpublished). The most important predators of I. phlegethontis seem to be Utah chub, Gila atraria, fish-eating ducks and gulls, and introduced aquatic species, particularly western mosquitofish, Gambusia affinis, largemouth bass, Micropterus salmoides, and bullfrog, Rana catesbeiana (Sigler \& Sigler 1987, 1996). Reproduction: Timing of spawning is a function of temperature and sunlight. Spawning takes place intermittently from spring to early summer, at water temperatures above about $16^{\circ} \mathrm{C}$. Females produce from 300 to 2700 demersal adherent eggs (depending on female body size). The eggs $(0.75-1.25 \mathrm{~mm}$ diameter) hatch in 2 days, at water temperatures of about $22^{\circ} \mathrm{C}$. Iotichthys phlegethontis reaches maturity at 1 year of age. Total length at age 1 is about $25 \mathrm{~mm}$ (Crawford 1979; Sigler \& Sigler 1987; M.C. Belk unpublished). Threats: Because of the current limited distribution of I. phlegethontis, threats to any of the local populations may affect the viability of the entire species. Main threats are predation and competition with introduced fish species (mainly G. affinis in both cases), and habitat loss and degradation (Sigler \& Sigler 1987). Conservation action: The conservation agreement for I. phlegethontis was developed by a multi-agency team in 1998. It focuses on determining baseline population, life history, and habitat needs; determining and maintaining genetic integrity; enhancing, maintaining, and protecting habitat; selectively controlling nonnative species; expanding I. phlegethontis populations and range through reintroduction; monitoring populations and habitat; and developing a mitigation protocol for proposed water development and future habitat alteration (Perkins et al. 1998). These conservation efforts are intended to preclude the listing of $I$. phlegethontis under the United States Endangered Species Act.

Cope, E.D. 1874. On the Plagopterinnae and the ichthyology of Utah. Proc. Am. Philos. Soc. 14: $122-139$.

Crawford, M. 1979. Reproductive modes of the least chub (Iotichthys phlegethontis). M.S. thesis, University of Utah, Salt Lake City. 80 pp.

Page, L.M. \& B.M. Burr. 1991. Freshwater Fishes. Houghton Mifflin Company, Boston. 432 pp.

Perkins, M.J., L.D. Lentsch \& J. Mizzi. 1998. Conservation Agreement and Strategy for Least Chub (Iotichthys phlegethontis). Utah Department of Natural Resources, Division of Wildlife Resources, Salt Lake City. 35 pp.

Sigler, W.F. \& J.W. Sigler. 1987. Fishes of the Great Basin. University of Nevada Press, Reno. 425 pp. Sigler W.F. \& J.W. Sigler. 1996. Fishes of Utah, A Natural History. University of Utah Press, Salt Lake City. 375 pp. 